\title{
Reading and Analyzing Ethnographies through Literature Circles: A Praxis Model for Encouraging Multicultural Educators
}

\author{
Marilee Coles-Ritchie \\ Westminster College \\ United States
}

This study explores the process of implementing literature circles using ethnographies as the texts to better prepare teachers for multiculturall multilingual teaching contexts. Data collected by the course instructor and two of the participants, using a Critical Teacher Action Research (CTAR) methodology, indicate that participants think critically, connect to the texts and others, and identify ways to enhance school practice based on the funds of knowledge described in the ethnographic works when participating in literature circles. The author provides the process of implementing literature circles in teacher education courses and provides an action plan for further practice.

\author{
Literature Circles to Promote Multicultural Educators \\ Implementing Literature Circles \\ Method \\ Findings and Discussion \\ Remaining Challenges: Action Plan \\ Conclusion \\ Endnotes \\ References
}

\section{Literature Circles to Promote Multicultural Educators}

Quality teacher preparation continues to be one of the most influential factors in student learning (Boyd et al., 2009; Cochran-Smith \& Power, 2010; Darling-Hammond, Holtzman, Gatlin, \& Vasquez Heilig, 2005; Ravitch, 2010). One element of effective teacher preparation programs includes an approach to teacher education that situates learning in its context of development (Gutiérrez \& Vossoughi, 2010). In essence, teacher educators need to situate the learning of inservice and preservice teachers so that they can understand their students' backgrounds, languages, and interests more deeply, and then create a curriculum based on those funds of knowledge (González, Moll, \& Amati, 2005). One way to move toward this goal is to arrange students in literature circle groups (Daniel, 2002; 1994) to discuss ethnographies about the contexts of English learners (ELs) ${ }^{1}$.

Literature circles were first implemented in the field of education in the 90s as a way to engage students in reading meaningfully within the K-12 setting 
(Almasi, McKeown, \& Beck, 1996; Crapse, 1995; Dugan,1997). With the increasing engagement of a variety of learners, literacy researchers and classroom teachers conducted research involving many aspects of implementing literature circles in their classrooms and found that they increased comprehension and critical inquiry (Berne \& Clark, 2006; Lloyd, 2004; Long \& Gove, 2003; Rogers, 2002). In addition, literature circles are used to facilitate the literacy development of English learners (Fredricks, 2012; Lewis,1997; MartinezRoldan \& Lopez-Robertson,1999; McElvain, 2010; Shelton-Strong, 2012). In recent years, the practice of using literature circles has resurfaced and been reconfigured using online technology (Bowers-Campbell, 2011; Edmondson, 2012). Research also indicates that literature circles are used successfully with adults (Beeghly, 2005; McCall, 2010; Mills \& Jennings, 2011; Monroe-Baillargeon \& Shema, 2010).

Using this research as a foundation, I began implementing literature circles in two of the courses I teach (EDUC 311 English Learners in All Classrooms and TESL/MED 320/620 English Learners, Family and Community). By using literature circles, I hoped to create a teacher education course where the students further developed their understanding of the complex groups of learners they would teach. The purpose of this study was to explore what participants learned when I implemented literature circles with ethnographies in the classroom and to examine my own practice. The major guiding questions were:

1. In what ways, if any, does implementing literature circles support a community of learners in which participants can discuss the context and theories of ethnographies focusing on immigrant families?

2. In what ways, if any, can reading and discussing ethnographies that focus on the immigrant experience within school settings prepare teachers to work with ELs?

3. How can I improve the pedagogical practice of implementing literature circles in teacher education courses?

This study adds to education research literature by studying the implementation of literature circles in teacher education courses focusing on teaching ELs. In my course, students read ethnographies that may challenge them academically because they contain complex theories and writing style, rather than reading books for adolescents that are less difficult academically. My goal is that students will be able to understand the value of working in literature circles because they need their classmates to help clarify and discuss the difficult issues in the text, as Cantrell (2002) discovers in her study on using discussions about academic articles with adults in teacher education courses.

\section{Implementing Literature Circles}

In this section I explain how I implement literature circles in my courses. The first section explains the preliminary work of selecting the books to present 
to the students for each literature circle. The second section describes how I explain the process of implementing the literature circles. This process has been developed and refined as I have continually reflected and elicited feedback from my students through the process of using literature circles as a pedagogical practice.

\section{Choosing the Book}

I begin setting up literature circles by choosing five to six books for my class. Selected books are well-respected ethnographic works that address issues of language learning and immigrant life within a school context. These include The Inner World of the Immigrant Child by Christina Igoa (1995); Con Respeto: Bridging the Distance Between Culturally Diverse Families and Schools by Guadalupe Valdés (1996); Subtractive Schooling by Angela Valenzuela (1999); Learning and Not Learning English by Guadalupe Valdés (2001); Up Against Whiteness: Race, School and Immigrant Youth by Stacey Lee (2005); Made in America by Laurie Olsen (2008); Reflections of Place: Connected Lives of Navajo Women by Donna Deyhle (2009); and Mothers United by Andrea Dyrness (2011). Each of these books gives rich contextual data about the students and the schools they attend. Some focus more on the teachers of these students and others on the learners, but all illustrate the complexity of teaching English to immigrant students in the United States from various theoretical lenses.

As Goodall (2001) and Hall (1997) explain, no ethnographic work can represent reality with an all encompassing perspective. Ethnographies are studies that represent reality, "but reality is far more complex-more full, more radically diverse, and more whole - than a representation of it" (Goodall, p. 55). During the introduction and throughout the course, I spend a considerable amount of time explaining the importance of not essentializing a group of people based on one ethnography as I help them prepare their presentations. It is essential that I address the idea that each of these books also has some limitations. For example, Igoa and Valdez's books were written about two decades ago. I discuss how they need to read these books historically and analyze how some of the situations may or may not apply to current issues for immigrant students. When presenting the Deyhle' and Dyrness' ethnographies, I point out their discussions of being an insider/outsider within the research and how that lens shifts.

I present the books to the class by describing the content and giving background information about the author. Then, I pass the books around so they can feel them and browse. Students note their first and second choices on a piece of paper which I collect and use to arrange literature circle groups of four to six students. 


\section{Process}

When the groups are arranged, I explain the process of the literature circles and rationale. The students in each group have an initial meeting and make a plan for four in-class discussion sessions. Each preservice teacher has a different role for every discussion meeting. I use the following roles for the literature circles, developed loosely on Daniels' (2002) role ideas: (a) Discussion Facilitator who is responsible for coming up with the discussion questions for the selection; (b) Literary Luminary who is responsible for choosing a few passages from the reading selection to share with the group; (c) Connector who shares text-to-self, text-to-world, or text-to-text connections made while reading; (d) Reporter who is responsible for summarizing the selection read; and (e) Scribe who collects the written material including the discussion questions, page number of passages, connections made, and the summary. After each group meeting, students write a personal reflection including their connection to the assigned reading in the book and the literature circle discussion.

As a culminating assessment, each literature group plans a visual presentation for the class. They include a summary of the book organized by salient themes, what they learned through reading the book, how they might arrange their own classroom based on funds of knowledge they learned through the ethnography, and finally their critical evaluation of the ethnography.

\section{Method}

To assess how the literature circles method impacted the students, I applied critical teacher action research (CTAR), which combines the work of Mills (2011), Tripp (1990), and Atewh, Kemmis, and Weeks (1998). Doing research through the qualitative action research framework directly informed my teaching. The exploration and data analysis highlighted areas I need to enhance, change, adjust, or remove when using this method. In this section I describe the setting, participants, data sources and collection method, and describe how I analyzed the data.

\section{Critical Action Research Study}

The CTAR framework includes the following elements: participation, direction, consciousness, and outcomes. I describe how I applied each of these elements as I conducted the study with the goal of improving pedagogical practice and the long term impact teachers have on students.

Participation means active learning from all those involved in the working context. In this research, the working context is the teacher education course. I played the role as both researcher and learner as I was the instructor trying to 
learn from this pedagogical practice. The students also played the role of researcher as they reflected and interviewed each other about the process of using literature circles in the classroom. We all had the goal of increasing our understanding of the complex sociocultural systems in which we reside while paying close attention to the ways ELs can be marginalized within school settings that often are not similar to their community practices.

The CTAR framework requires that the research has direction. I interpret this to mean that the research has to have a purpose for improving a certain context. In this action study, the inservice/preservice teachers and I wanted to improve our pedagogical practice when developing curricula and parent/community partnerships in relation to ELs. As a teacher educator, I also had the goal of modeling the process of using literature circles as a method for future teachers, as research supports its effectiveness for English learners in K12 classrooms.

The critical concept of CTAR is that consciousness needs to be explored. Part of this research is to reveal the embedded values each of the participants has concerning aspirations, ideologies, practices, and discourses about English learners, their families, their communities, and their linguistic practices. Through analyzing the reflective papers, discussions, interviews, and presentations, I hoped to understand the change processes that occurred during the method of using literature circles.

Finally, outcome is essential. By using CTAR, I am committed to developing, changing, and adjusting my method of teaching so as to minimize the ways teachers sometimes marginalize the ELs in their classrooms. In other words, this framework initiates action that could help improve school practices that disadvantage certain groups of students. In this research, my goal was to create a deeper understanding of local practices and community knowledge.

\section{Setting and Participants}

This study took place in a private, liberal arts college in the intermountain West. For three semesters, over two years, from Spring 2010-Spring 2012, I collected, organized, and analyzed data. The participants included 37 White middle-class/upper-class women; four White men; three self-identified mixed heritage Latina women; two international students, one from Korea and one from Saudi Arabia; and an African American woman. All students signed a consent form to participate in the study.

\section{Data Sources and Collection}

I collected data from open-ended surveys, students' written reflections after each literature circle meeting, literature circle notes by each group, rubrics and notes on the class visual presentations that highlighted themes, funds of knowledge observations, and ideas for their own teaching practice. In addition, 
two students, who wanted extra experience with research, and I conducted six semi-structured interviews.

Table 1. Data Sources and Types

\begin{tabular}{|l|l|l|}
\hline Data sources & Types of data & Collected by \\
\hline Student artifacts & $\begin{array}{l}\text { - Individual reflections on literature } \\
\text { meetings }\end{array}$ & $\begin{array}{l}\text { Group reflective summaries of the } \\
\text { literature circle meetings } \\
\text { Group visual presentations of the } \\
\text { ethnographies }\end{array}$ \\
\hline Interviews & $\begin{array}{l}6 \text { semi-structured interviews with } \\
\text { class members about the process }\end{array}$ & $\begin{array}{l}\text { Faculty researcher } \\
\text { Participants }\end{array}$ \\
\hline Field notes & $\begin{array}{l}\text { Observational notes and informal } \\
\text { conversations about the process }\end{array}$ & Faculty researcher \\
\hline Student journals & $\begin{array}{l}\text { On-going journals of insights from } \\
\text { reading the ethnographies and } \\
\text { observations of the process }\end{array}$ & Participants \\
\hline Survey & $\begin{array}{l}\text { Open-ended questions about the } \\
\text { learning and process of using } \\
\text { literature circles in the class }\end{array}$ & Faculty researcher \\
\hline
\end{tabular}

\section{Findings and Discussion}

I applied the constant comparison method (Strauss \& Corbin, 1990) of data analysis wherein I conducted open coding and then broke down, examined, compared, conceptualized, and then categorized the data by reading and rereading the data in conversation with the participants. To establish trustworthiness, I performed member checks with the participants who were in these classes by sending them the transcribed interviews and allowing them to clarify for accuracy.

For this paper, I organized the data on the value of using literature circles based on participant data, which gave evidence that literature circles are (a) a place for in-depth inquiry; (b) a place to connect and learn; and (c) a place to learn about useful practice in schools for English learners.

The participants in the study reported that they appreciated the experience of the literature circles because they learned more about the contexts of English learners and ways to support them in practice, that they enhanced their ability to conduct literature circles through participation, and that they developed an ability to think more deeply and critically. 


\section{Critical Inquiry}

One major theme that I identified was how the participants reflected often about the critical and in-depth thinking they were doing through the process of discussion in the literature circles. Almost all the participants referenced in-depth thinking in their individual reflection after participating in the literature circles such as, "Overall, I think our literature circles help us think deeper and really talk about issues that are still present today."

One example of critical inquiry that the participants wrote about, discussed, and presented was that of Whiteness. This emerged in all three semesters and in at least three different ethnographies. Most of the participants in the classes had experience with the concept of Whiteness through reading Unpacking the Invisible Knapsack (McIntosh, 1990). Some resisted the notion of White privilege in previous courses, while others acknowledged more awareness of privilege after reading it. Nonetheless, the notion of White privilege came through more profoundly as they discussed its implications based on reading about the children's experiences in the ethnographies. Pamela, a White woman in the bachelor's program who read Made in America, acknowledged:

When Sandra said, "People choose to live in Bayview because they want to raise their children in the real world." Reading on it is clear that she means is White, middle/upper class families when she uses the generalization "people." I am aware that I, too, have a mental segregation and compartmentalized view of people. How do we overcome these deeply rooted American tendencies?

Pamela's awareness of Whiteness and her own "mental segregation and compartmentalized view of people" became clearer as she read about a real situation involving Whiteness in the book and discussed it with her group members. She connected with Sandra and recognized her own compliance. She also acknowledges her desire to overcome the pervasiveness of Whiteness. In her literature circle group, this theme was a thread throughout their discussions, and it was a part of their group presentation.

Doug, a White man in his early 20 s who read Up Against Whiteness, had an ongoing battle with the author over the idea of Whiteness. In his first reflection he wrote,

Throughout the book the author states that the culture of the United States in "whiteness." This I do not agree with. I believe that much of the misunderstandings between cultures lies in the upper generations, especially the "baby-boomers" who were directly impacted by the Vietnam War.

In the literature circle discussions, much of their group's talk revolved around the idea of racism and Whiteness and the feeling that they (as a younger generation in their 20s) were being lumped in with a more racist older generation. Their 
discussions were so engaging that others, who were not taking the same class but happened to study in the same area, often joined in with the discussion. It was not until the end of the semester that Doug felt as if he understood what the author was trying to address. In his group's presentation on the last day of class, he said,

After resenting the way the book pointed to the 'White Devil' for most of the semester, I am attempting to be more open-minded by trying to understand the struggles of the Hmong, I just think that we have never been faced with anything remotely close, therefore we cannot fully understand their struggles.

Doug's investment in trying to understand perspectives throughout the semester points to the critical inquiry that went on in his group's discussions. It also points to the consciousness discussed in the CTAR framework. It reveals the embedded values that both Doug and Pamela had about the discourses of Whiteness inherent in their lived experience. Their consciousness about their own ideological approaches and assumptions about English learners was challenged so that they were pushed to reexamine their former assumptions and approaches.

The conversation did not end when the literature circle time ended. Another participant summed up the experience well when she said:

I will definitely use literature circles. It holds students accountable for reading, but allows for multiple interpretations of a text. More work for students than just a comprehension quiz, but the learning is deeper and more meaningful. This required my most attentive reading.

In CTAR, one of critical elements of research is outcomes. This student states that she will use the literature circles approach because it "allows for multiple interpretations of a text." By allowing for multiple interpretations, this future teacher is working towards diminishing current marginalizing ways of approaching ELs in her classroom. Participants commented again and again about the critical inquiry they had to do to understand the text and apply it to their own understanding and experiences so that they could use it in their teaching contexts later. They relied on others in their group both to understand the difficult academic texts and to push their thinking when they disagreed with each other or the author.

\section{Connections to Text and Others}

Another predominant theme the students wrote about was the ability to connect to the text and with others' experiences based on the text. One participant wrote, "I was able to learn a lot about how my other group members relate to Igoa's experience and the experiences of her students." Another said, "I enjoy meeting in our literature circle because it gives me a chance to understand and hear the opinions of my peers in the class. Although we all want to become 
educators in the future, our opinions and views on education greatly differ." Amanda, a mixed-heritage White/Columbian woman in her early 20s, who read Con Respeto, grew up in a predominately White community. She acknowledged that she thought her mom was strange because she was not like the other White mothers in the neighborhood. After reading Con Respeto she realized that other Latina families had values and expectations similar to her mother's. She expressed the varied parenting styles that mirrored the families in Con Respeto and her own family:

In other families [in my neighborhood] it seemed like the kid ran the household, in a sense. It seems the mom would say, "What do you want to do?" or "Oh you're not happy, let me change it for you." Where with my mom she would say that's the way it is so live with it or get over it. I think I am completely different than anyone else. The book opened a lot of insight for me. I was able to understand my family better. (Interview, Fall 2009)

By sharing how she was "completely different" from everyone else in her literature group, she was able to facilitate an open discussion that benefited how the White women in her group viewed the lived experiences of these Latina mothers. Amanda expressed this idea in an interview,

The other students in the group were more surprised because they don't hear [Mexican American] perspective much. Some of their stereotypes changed. The literature circle discussions changed their ideas a lot. They were like, "I get it now." It also helped because they experienced it with their case studies too.

When this group presented, one of the group member's commented on how she learned a lot about the ways schooling and child rearing differed in her own home from the book. "Mostly," she said, "I learned from hearing Amanda talk about her connections with the book based on her own family experience." Through the semester these texts to self connections strengthened the members' ability to view others' complex sociocultural systems with more depth.

Cathy, who read Mother's United, added, "As educators it is such an important quality to be able to incorporate what you already know and also what you can learn from the things that others know about the world." Finally, a participant, who is a mother, explained her personal connection when reading Mother's United: "I am happy I had the opportunity to read this novel because it really helped me dig deep within my own belief systems and re-evaluate what I thought I already knew about myself. I would recommend other parents read this book, especially parents that are in the education field." The connections that the participants made were significant. They indicated that the open format and specific roles in the literature circles allowed them to connect with the text in meaningful ways and with each other.

Not only did the students connect to the texts, but they were also able to view the texts as a story from one perspective that they didn't relate to on a personal level. Amanda said, "It's important for me to remind my peers that this is 
one Mexican-American experience of poor families living on the border. I worry that some of them start to generalize the experience." As the instructor, I felt it was important to continue to remind students that the experience they were reading would help them understand the depth of the lived experiences of the people they read about, but they had to remind themselves continually that the ethnography was just one story.

\section{Future Schooling Practices Enhanced}

One of my goals for implementing literature circles was that they would provide a way for preservice teachers to learn more about how to plan curriculum, engage in parent outreach, and interact with students in their classrooms, future and present, who come from diverse sociocultural systems that may be different than their own. In their individual reflections, presentations and surveys, many students wrote about what they learned through this process and how they might apply these ideas to future practice.

Elaine, a White woman in her early 20 s read Reflections of Place: Connected Lives of Navajo Women and was moved by what she learned about Navajo women in Deyhle's (2009) ethnography. Growing up in Utah, she had heard a different historical perspective of the Navajo from what she read from the Navajo women's' perspectives in the book. She explained that what she learned from engaging with this text was the need to "unlearn" (Wink, 2011):

Especially knowing not to look at things the way we've been trained [growing up]. Just being more open-minded and aware of the stereotypes and not to follow them. We are trained to ignore and not do anything about it. We should be more aware and approachable.

Elaine acknowledged that she needs to be "aware of the stereotypes" and not to ignore what has happened to groups of marginalized people historically. Her idea of being open-minded was also echoed by other students. Cathy expressed this "aha" moment, "You must know your students. I learned that what I consider to be the 'norm' may not really be 'normal' to other people. I have been humbled by the literature circles as well as informed."

The other main idea shared was that of giving more support to the ELs in their classrooms. A participant reading Igoa's book wrote, "All of us realized that it isn't the method that is important, it is the student first." Carolina said, "And as a teacher I think that I need to make sure that I give support and feed back especially to my students that have had different experience. So that they can share with the class, the class can learn from them. I learned a lot about just supporting a student." Another wrote, "However, creating a trusting, safe, and respectful environment is something that I stress over as an inexperienced educator. I want this to be my focus as a new teacher fresh from college because I feel that without confianza, any other efforts to learn are thwarted." 
In addition to supporting students, participants had an enhanced view about family and community involvement. They revealed a sense of consciousness about the context they were reading and how they might apply it in the future. Those who read Con Respeto and Mother's United especially commented on relying on family and community involvement more in their classrooms and schools. One said, "I learned that their parents have so much more to offer than we give them credit for!" Another added, "So often teachers think that parents do not care about anything or just cause another roadblock or annoyance, but they can actually provide a lot of really good insight about their children's lives and some suggestions for what would work out best in a school for their kids." These reflections indicated that the participants were reaching into their past experiences and connecting them to new ones created by engaging with the ethnographies in meaningful ways.

Overall the participants overwhelmingly expressed the value of literature circles. They thought deeply and inquired about issues presented in the book through discussion and reading. They connected to their own experience, their group members, and the children in the books they read. In addition they commented on the complexity of the lived experiences.

\section{Remaining Challenges: Action Plan}

The final goal of CTAR is that the data collected and analyzed should influence future teaching through outcomes. Throughout the three semesters that I collected data, I learned from students through individual reflections, group summaries, group presentations, interviews, survey data, and my own field notes. All students surveyed said that I should continue to use the literature circles. Some of the reasons they noted included learning from the texts in more depth, critical thinking, learning from others, and a deepened understanding about the lives of English learners. They also had suggestions on how to make the literature groups more effective. The concerns were more about logistics than about the choice of the books or the content. The themes discussed below impact the future direction of how I apply literature circles in my courses.

\section{Time in Literature Circles}

Many participants suggested that they needed more time to discuss the book. Others said that they had enough or too much time. When I asked them why they needed more or less time, the students who wanted less time usually attributed that to some members not being prepared with their roles or reading. Generally, participants who said they had too much time were in groups where some of the members were missing or that had fewer members in the group. Those who wanted more time usually were in groups with at least four members and had participants who were prepared with their reading and role assignment. It was difficult to provide more time due to the intense course content. Based on 
the feedback, I plan to assign four to five students per group based on the book they choose. I will also provide more time in the $2^{\text {nd }}$ and $3^{\text {rd }}$ meeting times when the participants are fully engaged in the books to allow for processing.

\section{Group Dynamics}

Any time students are assigned to work in groups together on a task, various interpersonal dynamics occur. I find the balance between being available for groups and allowing the participants to discuss the book on their own a bit of a challenge. I usually roam around the various rooms where the students meet to show that I am available if they need to ask questions. Most students say that they appreciate the "freedom they have to discuss the book with peers." When participants submit their individual reflections after each literature circle group meeting, they often comment on the group dynamics. Sometimes they complain that the other members in their group do not come prepared with their role assignment or that they have not read their assigned reading. These complaints are rare, however, since most participants enjoy reading the books that they chose. I realized that I do need to have a safety net of support for groups. Besides continuing with the individual reflections, I will have the participants submit a written self evaluation and evaluation of the group members that will be a part of their grade. I will also make them aware more clearly that I am available to consult with groups and individuals when needed.

\section{Structure of Presentation}

In groups, participants create a visual presentation to share with the class. I provide a rubric that provides them a structure. The rubric asks them to summarize the ethnography briefly, identify major themes in the ethnography supported by direct quotes and stories, describe what they learned from reading, explain how they might set up their classrooms based on the funds of knowledge described, and finally decide if they would recommend the ethnography to other educators and why. This task is difficult for some groups. They often spend too much time summarizing and focus less on identifying and supporting themes. Also, some have difficulty using the experiences of the families and communities they read about to construct beneficial classroom curriculum. As this is one of the most important goals of the research, I need to provide more support for them. Thein, Guise, Sloan and Long (2011) discuss the difficulty young readers have with understanding political texts. While the participants in this study are adults, they are reading advanced academic texts that include complex political, historical, and cultural situations. With this in mind, I realize that I need to provide more consultation for the groups as they are planning their presentations by asking them thought-provoking and guiding questions. I also need to share examples of successful presentations as models. Finally, I need to rework the rubric to give more specific guidelines. 


\section{Conclusion}

Using literature circles with preservice and inservice educators is a valuable tool for learning more about the complex contexts of ELs' lives. The ethnographies describe teachers who have faced the challenges and joys of working with immigrant students or the experience from the perspectives of immigrant students who attended the schools. By drawing on the experiences related in the texts, participants begin to appreciate teaching language as a historical, social, and political act that is extremely complex and difficult but also rewarding. Through reading about experiences of immigrant students, they observe how language belongs to students and their communities and how it impacts their daily lives in real and meaningful ways. By experiencing literature circles first hand, the participants are able to see how they can understand the complex texts by discussing ideas with each other and hearing how each member interpreted the text differently based on their own lived experiences. The rich data in the ethnographies allow them to experience vicariously the context of ELs' lives, an experience which is essential for educators who will teach in diverse multilingual and multicultural settings.

\section{Endnotes}

1. I believe all labels given to people are problematic. I choose to use English learners (ELs) - a label applied to students who enter the schools with a home language other than English because of its prevalence in the recent language education literature. The focus of the term is on students learning English to succeed in school. Unfortunately, the use of this label ignores a wide range of knowledge and expertise the student brings to school other than English.

2. The texts from the participants were not edited.

\section{References}

Almasi, J. F., McKeown, M. G., \& Beck, I. L. (1996). The nature of engaged reading in classroom discussions of literature. Journal of Literacy Research, 28(1), 107-146.

Atweh, B., Kemmis, S., \& Weeks, P. (Eds.) (1998) Action research in practice: Partnership for social justice in education. London, UK: Routledge.

Beeghly, D. G. (2005). It's about time: Using electronic literature discussion groups with adult learners. Journal of Adolescent \& Adult Literacy, 49(1), 12-21. 
Berne, J. I. \& Clark, K. F. (2006). Comprehension strategy use during peer-led discussions of text: Ninth graders tackle "The Lottery." Journal of Adolescent \& Adult Literacy, 49(8), 674-686.

Bowers-Campbell, J. (2011). Take it out of class: Exploring virtual literature circles. Journal of Adolescent \& Adult Literacy, 54(8), 557-567.

Boyd, D., Grossman, P., Lankford, H., Loeb, S., \& Wyckoff, J. (2009). Teacher preparation and student achievement. Educational Evaluation and Policy Analysis, 31, 416-440.

Cantrell, S. (2002). Promoting talk: A framework for reading discussions in teacher education courses. Journal of Adolescent and Adult Literacy, 45, 642-651.

Cochran-Smith, M., \& Power, C. (2010). The key to changing the teaching profession. New Directions for Teacher Preparation, 67(8), 6-13.

Crapse, L. (1995). Helping students construct meaning through their own questions. Journal of Reading, 38(5), 389-390.

Daniels, H. (1994). Literature circles: Voice and choice in the student-centered classroom. Markham, ON: Pembroke Publishers Ltd.

Daniels, H. (2002). Literature circles: Voice and choice in book clubs and reading groups. Portland, ME: Stenhouse.

Darling-Hammond, L., Holtzman, D., Gatlin, S., \& Vasquez Heilig, J. (2005). Does teacher preparation matter? Evidence about teacher certification, teach for America, and teacher effectiveness. Education Policy Analysis Archives, 13(42), 1-51.

Deyhle, D. (2009). Reflections in place: Connected lives of Navajo women. Tucson, AZ: The University of Arizona Press.

Dugan, J. (1997). Transactional literature discussions: Engaging students in the appreciation and understanding of literature. The Reading Teacher, 51(2), 86-96.

Dyrness, A. (2011). Mother's united: An immigrant struggle for socially just education. Minneapolis, MN: University of Minnesota Press.

Edmondson, E. (2012). Wiki literature circles: Creating digital learning communities. English Journal, 101(4), 43-49.

Fredricks, L. (2012). The benefits and challenges of culturally responsive EFL critical literature circles. Journal of Adolescent \& Adult Literacy, 55(6), 494-504.

Goodall, L. (2001). Writing the new ethnography. Walnut Creek, CA: Altamira Press.

González, N., Moll, L., \& Amanti, C. (2005). Funds of knowledge: Theorizing practices in households, communities, and classrooms. Mahwah, NJ: Erlbaum. 
Gutiérrez, K., \& Vossoughi, S. (2010). Lifting off the ground to return anew: Documenting and designing for equity and transformation through social design experiments. Journal of Teacher Education. 61(1-2), 100-117.

Hall, S. (1997). Cultural representations and signifying practices. London, UK: Sage Publications.

Igoa, C. (1995). The inner world of the immigrant child. Mahwah, NJ: Erlbaum.

Lee, S. (2005). Up against whiteness: Race, school, and immigrant youth. New York, NY: Teachers College Press.

Lewis, C. (1997). The social drama of literature discussions in a fifth/sixth grade classroom. Research in the Teaching of English, 31(2), 163-204.

Lloyd, S. L. (2004). Using comprehension strategies as a springboard for student talk. Journal of Adolescent \& Adult Literacy, 48(2), 114-124.

Long, T., \& Gove, M. K. (2003). How engagement strategies and literature circles promote critical response in a fourth-grade, urban classroom. Reading Teacher, 57(4), 350-361.

Martinez-Roldan, C. M., \& Lopez-Robertson, J. M. (1999). Initiating literature circles in a first-grade bilingual classroom. Reading Teacher, 53(4), 270281.

McCall, A. L. (2010). Teaching powerful social studies: Ideas through literature circles. Social Studies, 101(4), 152-159.

McElvain, C. M. (2010). Transactional literature circles and the reading comprehension of English learners in the mainstream classroom. Journal of Research in Reading, 33(2), 178-205.

McIntosh, P. (1990). White privilege: Unpacking the invisible knapsack. Independent School, 49(2), 31-36.

Mills, G. (2011). Action research: A Guide for the teacher researcher. Columbus, OH: Prentice Hall.

Mills, H., \& Jennings, L. (2011). Talking about talk: Reclaiming the value and power of literature circles. The Reading Teacher, 64(8), 590-598.

Monroe-Baillargeon, A., \& Shema, A. L. (2010). Time to talk: An urban school's use of literature circles to create a professional learning community. Education \& Urban Society, 42(6), 651-673.

Ravitch, D. (2010). The life and death of the great American school system: How testing and choice are undermining education. New York, NY: Perseus.

Rogers, R. (2002). "'That's what you're here for, you're suppose to tell us": Teaching and learning critical literacy. Journal of Adolescent \& Adult Literacy, 45(8), 772.

Shelton-Strong, S. J. (2012). Literature circles in ELT. English Language Teachers Journal, 66(2), 214-223. 
Strauss, A., \& Corbin, J. (1990). Basics of qualitative research: Grounded theory procedures and techniques. Newbury Park, CA: Sage.

Thein, A., Guise, M., \& Sloan, D. (2011). Problematizing literature circles as forums for discussion of multicultural and political texts. Journal of Adolescent \& Adult Literacy, 55(1), 15-24.

Tripp, D. (1990). Socially critical action research. Theory into Practice, 29(3). 158-166.

Valdés, G. (1996). Con respeto: Bridging the distance between culturally diverse families and schools. New York, NY: Teachers College Press.

Valdés, G. (2001). Learning and not learning English: Latino students in American schools. New York, NY: Teachers College Press.

Valenzuela, A. (1999). Subtractive schooling. New York, NY: State University of New York Press.

Wink, J. (2011). Critical pedagogy: Notes from the real world. Boston, MA: Pearson. 